\title{
Denitrification in a binary culture and thiocyanate metabolism in Thiohalophilus thiocyanoxidans gen. nov. sp. nov. - a moderately halophilic chemolithoautotrophic sulfur-oxidizing Gammaproteobacterium from hypersaline lakes
}

\author{
Dimitry Y. Sorokin - Tatjana P. Tourova • \\ Ekatherina Y. Bezsoudnova • Arjan Pol • Gerard Muyzer
}

Received: 5 September 2006 / Revised: 9 November 2006 / Accepted: 8 December 2006 / Published online: 10 January 2007

(C) Springer-Verlag 2007

\begin{abstract}
Anaerobic enrichment culture with thiocyanate as electron donor and nitrate as electron acceptor at $2 \mathrm{M} \mathrm{NaCl}$ inoculated with a mixture of sediments from hypersaline lakes in Kulunda Steppe (Altai, Russia) resulted in a selection of a binary consortium of moderately halophilic, obligately chemolithoautotrophic sulfur-oxidizing bacteria (SOB) capable of complete denitrification of nitrate with thiosulfate as the electron donor. One consortium member, strain HRhD 3sp, was isolated into pure culture with nitrate and thiosulfate using a density gradient. This strain was responsible for the reduction of nitrate to nitrite in the consortium, while a second strain, HRhD 2, isolated under microoxic conditions with thiosulfate as substrate, was capable of anaerobic growth with nitrite
\end{abstract}

Electronic supplementary material The online version of this article (doi:10.1007/s00203-006-0208-3) contains supplementary material, which is available to authorized users.

D. Y. Sorokin $(\bowtie) \cdot$ T. P. Tourova

Winogradsky Institute of Microbiology,

Russian Academy of Sciences, Prospect 60-let Octyabrya,

7/2, 117312 Moscow, Russia

e-mail: soroc@inmi.host.ru

e-mail: D.Y.Sorokin@tnw.tudelft.nl

D. Y. Sorokin · G. Muyzer

Department of Biotechnology,

Delft University of Technology, Delft, The Netherlands

A. Pol

Department of Microbiology,

Radboud University of Nijmegen,

Nijmegen, The Netherlands

E. Y. Bezsoudnova

A. N. Bach Institute of Biochemistry,

Russian Academy of Sciences, Moscow, Russia and thiosulfate. Nitrite, either as substrate or as product, was already toxic at very low concentrations for both strains. As a result, optimal growth under anaerobic conditions could only be achieved within the consortium. On the basis of phylogenetic analysis, both organisms were identified as new lineages within the Gammaproteobacteria. As well as thiosulfate, strain HRhD 2 can also use thiocyanate as electron donor, representing a first halophilic SOB capable of growth with thiocyanate at $2-4 \mathrm{M} \mathrm{NaCl}$. Product and enzymatic analysis identified the "carbonyl sulfide (COS) pathway" of primary thiocyanate degradation in this new species. On the basis of phenotypic and genetic analysis, strain HRhD 2 is proposed to be assigned to a new genus and species Thiohalophilus thiocyanoxidans.

Keywords Halophilic sulfur-oxidizing bacteria (SOB) Hypersaline lakes · Thiodenitrification - Thiocyanate . Thiocyanate hydrolase

\section{Introduction}

Lithoautotrophic sulfur-oxidizing bacteria (SOB) play an important role in mineral cycling in environments where reduced sulfur compounds are actively generated by sulfate-reducing bacteria, such as surface sediments and chemocline layers of stratified waters. Among the chemolithotrophic bacteria, SOB have the best chance to adapt to extreme conditions, such as high salt, because of the high energy yield obtained from the eight-electron oxidation of sulfide/thiosulfate to sulfate (Oren 1999). Nonetheless, until now, the only species from this group, a neutrophilic moderately 
halophilic $\mathrm{SOB}$ able to grow at $\mathrm{NaCl}$ concentrations up to $4 \mathrm{M} \mathrm{NaCl}$, but still with an optimum growth at much lower salinity, was discovered 15 years ago in an Australian hypersaline lake (Wood and Kelly 1991) and is currently known as Halothiobacillus halophilus (Kelly et al. 1998; Kelly and Wood 2000).

Our research on the diversity of natronophilic (sodium carbonate-loving) SOB inhabiting soda lakes demonstrated the widespread potential of chemolithoautotrophic SOB to grow at high $\mathrm{pH}$ in sodium carbonate brines (Sorokin and Kuenen 2005a, b). However, apart of the $\mathrm{pH}$, several other physicochemical properties of sodium carbonate (weak electrolyte) are different from those of $\mathrm{NaCl}$ (strong electrolyte). Therefore, different adaptation strategy/phenotypes might be expected to thrive in chloride-sulfate hypersaline habitats with neutral $\mathrm{pH}$. Recently, we detected an unexpectedly large diversity of moderate to extremely halophilic SOB inhabiting sediments of hypersaline habitats with neutral $\mathrm{pH}$. It included at least four groups which formed new lineages within the Gammaproteobacteria (Sorokin et al. 2006).

The potential to grow anaerobically with nitrogen oxides as the electron acceptor is one of the important properties of several SOB species, such as Thiobacillus denitrificans (a neutrophilic Betaproteobacterium) or Thioalkalivibrio denitrificans (a haloalkaliphilic Gammaproteobacterium). This potential allows such SOB to be active in the absence of oxygen, linking two important inorganic element cycles. Our investigations of alkaliphilic SOB in soda lakes enrichments with thiosulfate and nitrate always resulted in the selection of a mixture of incompletely denitrifying SOB that can only drive a complete nitrate reduction in association, such as with the nitrite-producing Thioalkalivibrio nitratireducens and nitrite-reducing Thioalkalivibrio denitrificans (Sorokin et al. 2003b). Use of another, more difficult to utilize, electron donor, such as thiocyanate, resulted in the isolation of a complete denitrifier, Thioalkalivibrio thiocyanodenitrificans (Sorokin et al. 2004).

In contrast, enrichments with the sediments from hypersaline neutral habitats gave opposite results. With thiosulfate as the electron donor, completely denitrifying halophilic SOB were dominating in the enrichments at $2 \mathrm{M} \mathrm{NaCl}$, while replacement of thiosulfate by thiocyanate resulted in the selection of a coculture of two incompletely denitrifying SOB species. The latter was subject of the present investigation. The consortium consisted of two moderately halophilic SOB species, representing new lineages in the Gammaproteobacteria. One of them can utilize thiocyanate as the electron donor through the "carbonyl sulfide (COS) pathway"
(Kelly and Baker 1990), being the first example of a sulfur-oxidizing bacterium able to grow with thiocyanate at extremely high $\mathrm{NaCl}$ concentrations. It is described here as a new genus and species.

\section{Materials and methods}

\section{Sediment samples}

A mixture of sediment samples from twenty hypersaline chloride-sulfate hypersaline lakes in Kulunda Steppe (South-Western Siberia, Altai, Russia) was used as the inoculum for the enrichment cultures. The lakes contained $10-38 \%(w / v)$ total salt with $\mathrm{Na}^{+}, \mathrm{Cl}^{-}$ and $\mathrm{SO}_{4}^{2-}$ as dominant ions. The $\mathrm{pH}$ of the brines varied from 7.5 to 8.5 (Sorokin et al. 2006). Sediment cores were taken with a minicorer from the top $10 \mathrm{~cm}$ layer. Most of the samples were black, silty mud with a strong sulfide odor.

\section{Enrichment and cultivation conditions}

Basic mineral medium used for enrichment, isolation and cultivation of halophilic SOB contained $0.5-4 \mathrm{M}$ $\mathrm{NaCl}, 10 \mathrm{mM} \mathrm{K}_{2} \mathrm{HPO}_{4}$ and $5 \mathrm{mM} \mathrm{NH}_{4} \mathrm{Cl}$. The $\mathrm{pH}$ was adjusted to 7.3 with $1 \mathrm{M} \mathrm{HCl}$. After sterilization, the medium was supplemented with $1 \mathrm{ml} \mathrm{l}^{-1}$ of trace metal solution (Pfennig and Lippert 1966), $2 \mathrm{mM} \mathrm{MgCl}$ and variable amounts of $\mathrm{NaHCO}_{3}$ from filter-sterilized $1 \mathrm{M}$ stock solution ( $\mathrm{pH}$ 8.0) as a carbon source and an additional alkaline buffer. Sodium thiosulfate (Fluka) and potassium thiocyanate (Merck) were used as electron donors and S-source at $5-35 \mathrm{mM}$ and $5-10 \mathrm{mM}$ final concentrations, respectively. During cultivation the $\mathrm{pH}$ was maintained within 7.2-7.8, either by addition of $\mathrm{NaHCO}_{3}$ or by injection of sterile $\mathrm{CO}_{2}$. Aerobic cultivation was performed in closed serum bottles with $10 \%$ liquid either statically or on a rotary shaker at $100 \mathrm{rpm}$ at $30^{\circ} \mathrm{C}$. For anaerobic cultivation, the same bottles were used with $80 \%$ liquid medium and argon in the gas phase. The electron acceptors used were nitrate (5$20 \mathrm{mM}$ ) or nitrite (1-5 mM). Solid medium containing $1-2 \mathrm{M} \mathrm{NaCl}$ was prepared by $1: 1$ mixing of $2-4 \mathrm{M} \mathrm{NaCl}$ complete liquid medium with $4 \%(\mathrm{w} / \mathrm{v})$ agar (Noble, Difco) at $50^{\circ} \mathrm{C}$. The plates were incubated in closed jars either aerobically at $2 \% \mathrm{O}_{2}$ or anaerobically under argon with an oxygen-consuming catalyst (Oxoid). Dialysis cultivation was performed in $1 \mathrm{~L}$ flasks filled with anaerobic mineral medium containing $2 \mathrm{M} \mathrm{NaCl}$. A Centricon tube (Millipore) with the $10 \mathrm{kDa}$ cut-off membrane, sterilized with ethanol, was placed inside to allow diffusion exchange between the culture inside the 
tube $(20 \mathrm{ml})$ and the external medium. The culture was stirred by a magnetic bar inside the tube. The sucrose density gradient was prepared from 10 and $40 \%$ (w/v) filter-sterilized solutions in $1 \mathrm{M} \mathrm{NaCl}$. Gradient was formed in $25 \mathrm{ml}$ sterile centrifuge tube after layering 2 solutions within $2 \mathrm{~h}$ horizontally. $1 \mathrm{ml}$ of concentrated cells from the coculture was placed on the top of sucrose solution and the cells were separated by centrifugation at 10,000 rpm for 10-30 $\mathrm{min}$.

\section{Activity tests}

To determine the rates of conversion of nitrogen and sulfur compounds under various conditions, washed cells or cell-free extracts (obtained by sonication) were incubated from 0.5 to 10 hours in $10 \mathrm{ml}$ serum bottles with either butyl- or grey-rubber stoppers [for carbonyl sulfide (COS) metabolism]. Aerobic incubation was performed with $2 \mathrm{ml}$ reaction mixture statically, while for anaerobic tests $5 \mathrm{ml}$ liquid was incubated under argon. In experiments on COS hydrolysis, total sulfide was fixed by adding $1 \mathrm{ml}$ of $10 \%(\mathrm{w} / \mathrm{v})$ zinc acetate with a syringe followed by $3 \mathrm{~min}$ vigorous shaking to absorb $\mathrm{H}_{2} \mathrm{~S}$ from the gas phase. The oxidation rates of sulfur compounds by washed cells were also tested using an oxygen electrode (Yellow Springs, Ohio, USA). Cyanase activity in whole cells or in cell-free extracts was measured by following ammonium formation from $2 \mathrm{mM}$ sodium cyanate in the presence of $10 \mathrm{mM} \mathrm{NaH}-$ $\mathrm{CO}_{3}$ during $1 \mathrm{~h}$ at $30^{\circ} \mathrm{C}$. Activity of nitrate-reductase (NAR) and nitrite-reductase (NIR) were measured in cell free extracts with reduced methyl viologen as the electron donor (Murillo et al. 1999).

\section{Enzyme purification}

Freeze-dried biomass ( $1.6 \mathrm{~g})$ prepared from the cells grown with thiocyanate at $2 \mathrm{M} \mathrm{NaCl}$ was rewetted in $0.1 \mathrm{M}$ potassium phosphate buffer, $\mathrm{pH} 7.5$ and disrupted in Hughes pressure cell at $220 \mathrm{~kg}\left(\mathrm{~cm}^{3}\right)^{-1}$. Ammonium sulfate was added to the resulting cell-free extract up to $30 \%$ saturation and after $1 \mathrm{~h}$ incubation at $4{ }^{\circ} \mathrm{C}$ the precipitate was discharged. The resulting supernatant was diluted 80 times and loaded onto a DEAE-Sepharose column $(1 \times 14 \mathrm{~cm}$, Fast Flow Amersham Biosciences) equilibrated with $50 \mathrm{mM}$ Tris$\mathrm{HCl}$. The proteins were eluted by a $\mathrm{NaCl}$ gradient from 0 to $0.5 \mathrm{M} \mathrm{NaCl}$ and the active fractions were pooled and concentrated using Ultraconcentration Cell (Millipore). Next purification step was performed on a gel filtration column Superdex ${ }^{\text {TM }} 200$ (10/300 Amersham Biosciences) equilibrated with $50 \mathrm{mM}$ Tris- $\mathrm{HCl} / 0.2 \mathrm{M}$ $\mathrm{NaCl}, \mathrm{pH} 7.8$, at $20^{\circ} \mathrm{C}$. An active fraction, obtained from this step, was contaminated with cyanase. To separate the thiocyanate hydrolase from the cyanase, a second anion-exchange column MonoQ 10/100 Gl (Amersham Biosciences) was employed equilibrated by $50 \mathrm{mM}$ Tris- $\mathrm{HCl}, \mathrm{pH} 8.0$, with $0-0.5 \mathrm{M} \mathrm{NaCl}$ gradient elution. Each purification stage was followed by protein gel electrophoresis of the active fraction(s) (Davis 1964; Laemmli 1970).

\section{Analytic procedures}

Nitrogen (nitrate, nitrite, ammonium, cyanate, $\mathrm{N}_{2} \mathrm{O}$ ) and sulfur (sulfide, thiosulfate, sulfate, thiocyanate, tetrathionate) compounds were analyzed as described previously (Sorokin et al., $2001 \mathrm{a}, \mathrm{b}$; 2004). COS was detected in $1 \mathrm{ml}$ gas samples by GC (model Packard $438 \mathrm{~A}$ ) with a $2 \mathrm{~m}$ glass column (4 mm ID) packed with Carbopack B HT100 (40/60 mesh) and $\mathrm{N}_{2}$ as a carrier gas at a flow rate of $80 \mathrm{ml} / \mathrm{min}$. Column temperature was $80^{\circ} \mathrm{C}$, detector (FPD) and injector temperature was $190^{\circ} \mathrm{C}$ (Derikx et al., 1990). Cell protein was analyzed by Lowry method after removal of interfering sulfur compounds either by washing (thiosulfate, thiocyanate) or by overnight extraction with acetone (sulfur). Cellular fatty acids were extracted with methanol-chloroform mixture and analyzed by GCMS according to Zhilina et al. (1997). For electron microscopy, the cells were suspended in $1 \mathrm{M} \mathrm{NaCl}, \mathrm{pH}$ 8 and immediately frozen at $-80^{\circ} \mathrm{C}$ until processing. The cells were thawed in $3 \%(\mathrm{v} / \mathrm{v})$ glutaraldehyde in $0.1 \mathrm{M}$ cacodylate buffer $+1 \mathrm{M} \mathrm{NaCl}, \mathrm{pH} 7$ for $2 \mathrm{~h}$ on ice, then washed in the same buffer. Cells were postfixed in $1 \%(\mathrm{w} / \mathrm{v}) \mathrm{OsO}_{4}+1 \mathrm{M} \mathrm{NaCl}$ for $3 \mathrm{~h}$ at room temperature, washed and stained overnight with $1 \%$ $(\mathrm{w} / \mathrm{v})$ uranyl acetate, dehydrated in an ethanol series and embedded in Epon resin. Thin sections were stained with $1 \%(\mathrm{w} / \mathrm{v})$ lead citrate.

\section{DNA analysis}

The isolation of the DNA and subsequent determination of the $\mathrm{G}+\mathrm{C}$ content was performed by the thermal denaturation/reassociation technique (Marmur, 1961). Genomic DNA for PCR was extracted from the cells using the UltraClean Soil DNA Extraction Kit (MolBio Laboratories, USA), following the manufacturer's instructions. The nearly complete $16 \mathrm{~S}$ rRNA gene was obtained from pure cultures using bacterial primers GM3F and GM4R (Schäfer \& Muyzer, 2001). The PCR products were purified from low-melting agarose using the Wizard PCR-Prep kit (Promega, USA) according to the manufacturer's instructions. Sequencing was performed using Big Dye Terminator v.3.1 
sequencing reaction kit at ABI 3730 DNA automatic sequencer (Applied Biosystems, Inc., USA). The sequences were first compared with those stored in GenBank using the BLAST algorithm. The sequences were aligned with those from the GenBank using CLUSTALW. Phylogenetic trees were reconstructed with four different algorithms using TREECONW program package (van de Peer \& de Wachter, 1994). The sequences of the 16S rRNA genes obtained in this work have been deposited in the GenBank under the accession numbers DQ469584 (strain HRhD 2) and DQ836238 (strain HRhD 3sp).

\section{Results}

Thiodenitrification in a mixed culture of halophilic SOB

In our study of thiocyanate degradation at high salt concentration by halophilic SOB from hypersaline lakes the aerobic enrichments did not result in stable cultures (Sorokin et al. 2006). In contrast, anaerobic enrichments at $1-2 \mathrm{M} \mathrm{NaCl}$ gave stable, albeit very slowly growing, mixed cultures where oxidation of thiocyanate to sulfate was linked to a complete reduction of nitrate to dinitrogen gas (Fig. 1a). However, serial dilutions with thiocyanate were positive only up to $10^{-4}$ with $4-5$ different morphotypes still present. Replacement of thiocyanate by thiosulfate eventually allowed the mixed culture to minimize to a binary coculture able to reduce nitrate to dinitrogen with $\mathrm{N}_{2} \mathrm{O}$ as a minor gaseous intermediate at 1-2 M NaCl (Fig. 1b). This association consisted of thin rods as the dominant morphotype and thick vibrios as the minor component (Fig. 2a). The mixed culture could not be separated under these conditions, which indicated that the minor component most probably initiated the reaction. When this type was diluted out to extinction $\left(10^{-8}\right)$, the second, more abundant organism, was not able to grow. The latter could be purified by two ways: (1) after serial dilutions with thiosulfate under microoxic conditions, and (2) on anaerobic plates with nitrite and thiosulfate directly from the mixed culture. The strain was designated HRhD 2 (Fig. 2b, d). When tested under anaerobic conditions, this strain could only grow with nitrite as the electron acceptor and at very low concentrations (below $1 \mathrm{mM}$ ). This made it clear, that the minor vibrio-shaped component of the association is a nitrate reducer. Its isolation in pure culture was possible only after selective physical enrichment by density gradient, which made it numerically dominant over HRhD 2. From this enriched material it was possible to purify the vibrio-shaped morphotype, designated strain
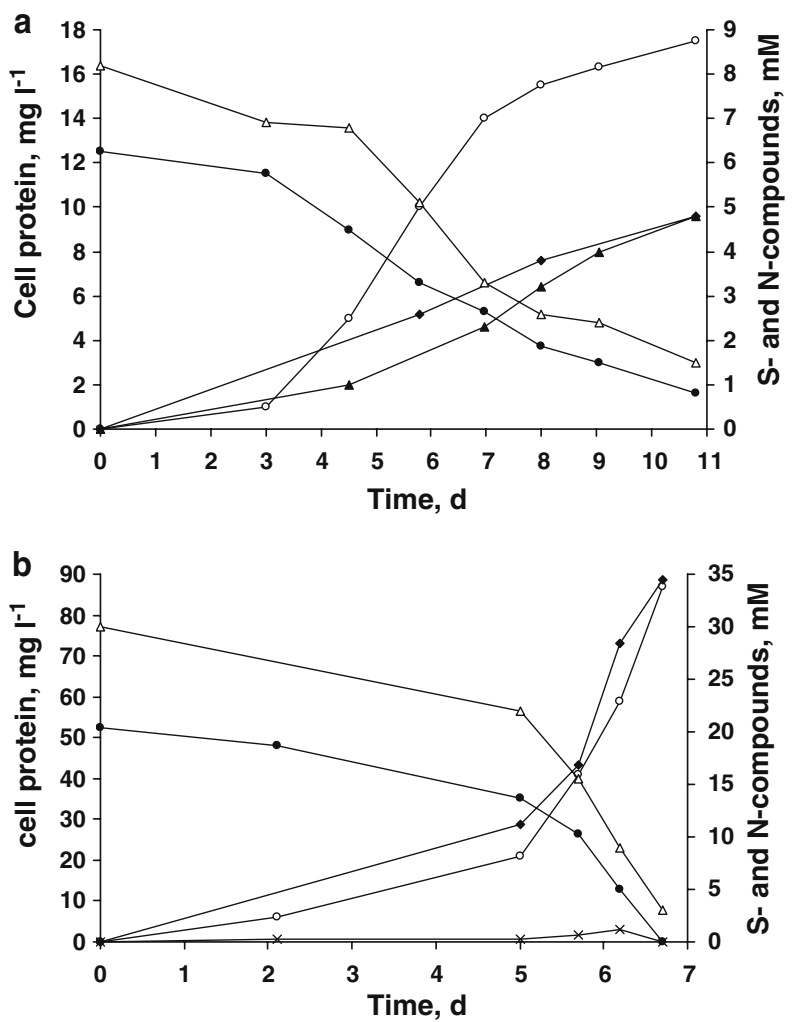

Fig. 1 Growth dynamics of halophilic thiodenitrifying mixed culture with thiocyanate at $1 \mathrm{M} \mathrm{NaCl}$ (a) and with thiosulfate at $2 \mathrm{M}$ $\mathrm{NaCl}$ (b). Open circles, biomass; closed circles, thiocyanate in (a) or thiosulfate in (b); open triangles, nitrate; closed triangles, ammonium; diamonds, sulfate; $\mathrm{x}, \mathrm{N}_{2} \mathrm{O}$

HRhD 3sp (Fig. 2, c), using the medium with $5 \mathrm{mM}$ nitrate and $2 \mathrm{mM}$ thiosulfate. Anaerobic growth of the nitrate-reducing strain $\mathrm{HRhD} 3 \mathrm{sp}$ in pure culture was very poor because of rapid inhibition by the accumulating nitrite - a final product of nitrate reduction. As soon as nitrite concentration reached $2-2.5 \mathrm{mM}$ the culture stopped growing and sulfur started to accumulate. Therefore toxicity of nitrite, both for the nitrate- and nitrite-reducing members of the halophilic thiodenitrifying coculture can be regarded as the major reason for them to work in association. This was confirmed in a dialysis culture of HRhD 3sp, whereby the removal of nitrite from the culture vessel allowed a much higher density and the complete oxidation of $10 \mathrm{mM}$ thiosulfate to sulfate (Supplementary Figure.).

Characteristics of the members of thiodenitrifying association

Comparative characteristics of two SOB strains isolated from the thiodenitrifying association are given in Table 1. Both HRhD strains are moderately halophilic, obligately chemolithoautotrophic SOB capable of 
Fig. 2 Cell morphology of halophilic thiodenitrifying bacteria from hypersaline habitats. a, binary culture grown anaerobically with thiosulfate and nitrate; $b, d$ pure culture of nitrite-reducing strain $\mathrm{HRhD} 2$; c, pure culture of nitrate-reducing strain HRhD 3sp. a-c, phase contrast microphotographs; $\mathrm{d}$, thin section, bar $=1 \mu \mathrm{m}$
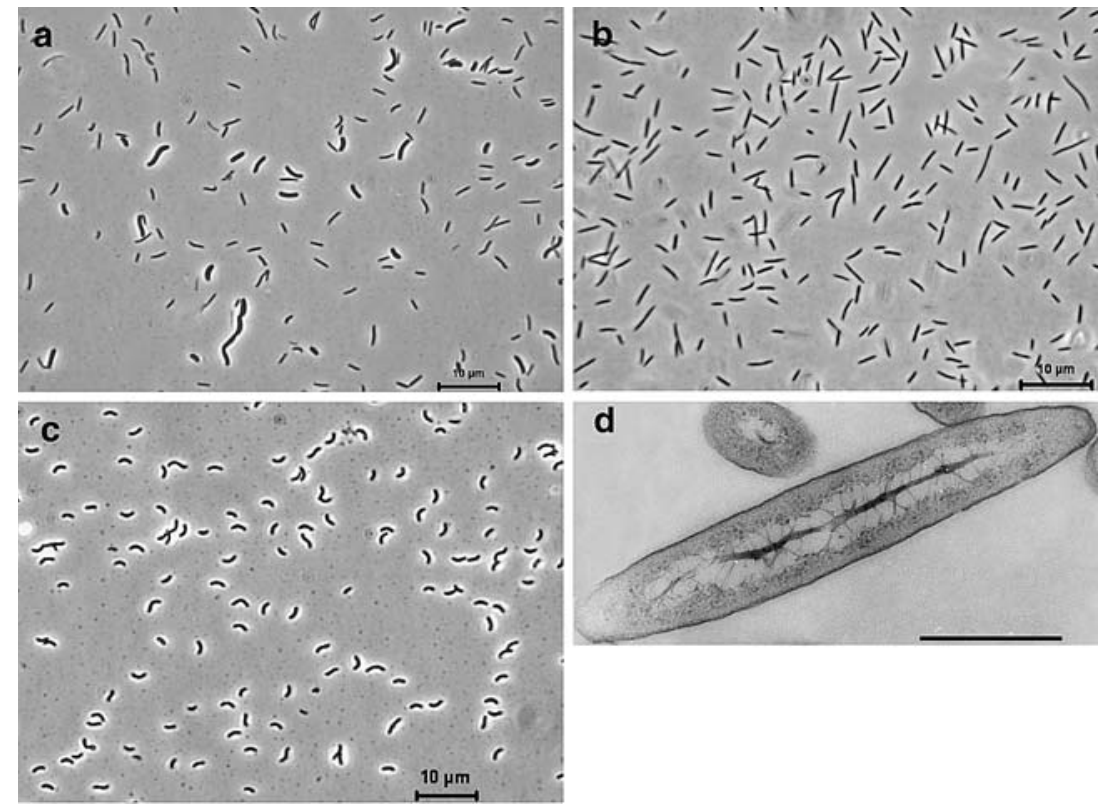

Table 1 Comparative properties of the two members of halophilic thiodenitrifying consortium

\begin{tabular}{|c|c|c|}
\hline Property & Strain HRhD 3sp & Strain HRhD 2 \\
\hline Role in the consortium & $\begin{array}{c}8 \mathrm{NO}_{3}^{-}+2 \mathrm{~S}_{2} \mathrm{O}_{3}^{2-}+2 \mathrm{H}_{2} \mathrm{O}>> \\
8 \mathrm{NO}_{2}^{-}+4 \mathrm{SO}_{4}^{2-}+4 \mathrm{H}^{+}\end{array}$ & $\begin{array}{c}8 \mathrm{NO}_{2}^{-}+3 \mathrm{~S}_{2} \mathrm{O}_{3}^{2-}+2 \mathrm{H}^{+}>> \\
4 \mathrm{~N}_{2}+6 \mathrm{SO}_{4}^{2-}+\mathrm{H}_{2} \mathrm{O}\end{array}$ \\
\hline $\begin{array}{l}\text { Average cell volume } \\
\text { in consortium }\left(\mu \mathrm{m}^{3}\right)\end{array}$ & 2.0 & 0.40 \\
\hline $\begin{array}{l}\text { Biomass in the } \\
\text { consortium ( } \% \text { from total) }\end{array}$ & $40-50$ & $50-60$ \\
\hline Growth with thiocyanate & - & + \\
\hline Aerobic growth with $\mathrm{S}_{2} \mathrm{O}_{3}^{2-}$ & at $<5 \% \mathrm{O}_{2}$ & at fully aerobic conditions \\
\hline $\begin{array}{l}\text { Growth inhibition } \\
\text { by nitrite }(\mathrm{mM})\end{array}$ & $2.5-3$ & 1 \\
\hline \multicolumn{3}{|l|}{$\begin{array}{l}\mu_{\max } \text { with } \mathrm{S}_{2} \mathrm{O}_{3}^{2-} \\
\text { at } 2 \mathrm{M} \mathrm{NaCl}^{-1}\left(\mathrm{~h}^{-1}\right)\end{array}$} \\
\hline anaerobic & 0.030 & 0.06 \\
\hline aerobic & 0.021 & 0.10 \\
\hline \multicolumn{3}{|l|}{$\mathrm{Y}$ at $2 \mathrm{M} \mathrm{NaCl}\left(\mathrm{mg}\right.$ protein $\left.\mathrm{mmol}^{-1}\right)$} \\
\hline aerobic with $\mathrm{S}_{2} \mathrm{O}_{3}^{2-}$ & 3.2 & 5.6 \\
\hline anaerobic with $\mathrm{S}_{2} \mathrm{O}_{3}^{2-}$ & 3.0 & 6.9 \\
\hline $\mathrm{NaCl}$ range for growth $(\mathrm{M})$ : & $1.0-2.5$ (opt. 1.0$)$ & $1.0-4.0$ (opt. $1.5-2.0$ ) \\
\hline \multicolumn{3}{|l|}{$\begin{array}{l}\text { Respiratory activity at } 2 \mathrm{M} \mathrm{NaCl} \\
\left(\text { nmol } \mathrm{O}_{2} \mathrm{mg}_{\text {protein }}^{-1} \mathrm{~min}^{-1}\right)\end{array}$} \\
\hline $\mathrm{NCS}^{-}$ & 0 & 110 \\
\hline $\mathrm{HS}^{-}$ & 120 & 360 \\
\hline $\mathrm{S}_{2} \mathrm{O}_{3}^{2-}$ & 100 & 280 \\
\hline $\mathrm{S}_{4}^{2} \mathrm{O}_{6}^{2-}$ & 0 & 55 \\
\hline $\mathrm{S}_{8}$ & 0 & 40 \\
\hline NAR (nmol mg protein ${ }^{-1} \min ^{-1}$ ) & 650 & 0 \\
\hline NIR (nmol mg protein $\left.{ }^{-1} \min ^{-1}\right)$ & 0 & 110 \\
\hline Yellow pigment & - & + \\
\hline DNA G $+\mathrm{C}$ content $(\mathrm{mol} \%)$ & 63.5 & 58.2 \\
\hline
\end{tabular}

utilizing sulfide and thiosulfate as electron donors. Strain HRhD 3sp is a nitrate reducer with high NAR activity, but it can not reduce nitrite or $\mathrm{N}_{2} \mathrm{O}$. The NAR activity is membrane-associated and was inhibited by $\mathrm{NaCl}$. The bacterium can also grow aerobically with thiosulfate, but only at low $\mathrm{O}_{2}$ concentrations $(<5 \%$ in the gas phase). It is characterized by a low growth rate, low yield and low respiratory activity. In contrast, the nitrite-reducing strain HRhD 2 grew well under fully aerobic conditions, had relatively high respiration rates with thiosulfate and sulfide, higher growth rates and high growth yield on thiosulfate, and a much higher 
salt tolerance. The growth yield of strain HRhD 2 was among the highest values known for sulfur-oxidizing chemoautotrophs (Kelly 1999). Also unusual was the higher efficiency of anaerobic growth, which might indicate the operation of different pathways for oxidizing thiosulfate under aerobic and anaerobic conditions. Furthermore, under aerobic conditions, this bacterium produced a membrane-bound, methanol-extractable yellow pigment with an absorption maximum at $410 \mathrm{~nm}$. The cells of HRhD 2, grown anaerobically with nitrite, can reduce nitrite and $\mathrm{N}_{2} \mathrm{O}$, but not nitrate in the presence of thiosulfate as the electron donor. Anaerobic growth with $\mathrm{N}_{2} \mathrm{O}$ as an electron acceptor was not observed. Spectroscopy indicated the presence of a cytochrome $c d_{1}$-type of nitrite reductase, the activity of which was mostly found in the soluble fraction of cell-free extract. In contrast to the NAR activity of HRhD 3sp, the NIR activity of HRhD 2 was stimulated by $\mathrm{NaCl}$ with an optimum at $3 \mathrm{M}$. The activity of $\mathrm{N}_{2} \mathrm{O}$ dependent thiosulfate oxidation by whole cells of $\mathrm{HRhD} 2$ had an optimum at $2 \mathrm{M} \mathrm{NaCl}$.

Aerobic growth of strain $\mathrm{HRhD} 2$ with thiocyanate

Since both isolates originated from the enrichment with thiocyanate as electron donor, they were tested for the ability to grow with thiocyanate under aerobic and anaerobic conditions. The nitrate-reducing strain HRhD 3sp did not grow, while the nitrite-reducing HRhD 2, after a relatively long adaptation period, started to grow with thiocyanate under aerobic conditions. Anaerobic growth with thiocyanate and nitrite was only observed in dialysis culture with $0.1 \mathrm{mM}$ nitrite in the outside medium. All further experiments were conducted under aerobic conditions.

Strain HRhD 2 grew aerobically with thiocyanate at $\mathrm{NaCl}$ concentration between 1 and $3 \mathrm{M}$, and after adaptation, up to $4 \mathrm{M}$. It is the first SOB representative capable of utilizing thiocyanate under these conditions. The maximum specific growth rate and growth yield with thiocyanate were $0.038 \mathrm{~h}^{-1}$ and $5.8 \mathrm{mg}$ protein $\mathrm{mmol}^{-1}$, respectively, at $1.5 \mathrm{M} \mathrm{NaCl}$. At $4 \mathrm{M} \mathrm{NaCl}$ the values decreased to $0.011 \mathrm{~h}^{-1}$ and $3.9 \mathrm{mg}$ protein $\mathrm{mmol}^{-1}$, respectively. Final products of thiocyanate metabolism were sulfate and ammonium (90-95 and $80-85 \%$ recovery). Cyanate $\left(\mathrm{CNO}^{-}\right)$was not detected.

Only cells grown with thiocyanate, but not with thiosulfate, were able to convert thiocyanate into sulfate, evident both from thiocyanate disappearance and oxygen consumption experiments. The maximum rate of thiocyanate-dependent respiration observed in washed cells at $2 \mathrm{M} \mathrm{NaCl}$ was $110 \mathrm{nmol} \mathrm{O}_{2}$ (mg protein $\mathrm{min})^{-1}$. The activity with thiosulfate was of the same magnitude, which was 2-3 times lower than in thiosulfate-grown cells, while the sulfide-oxidizing potential remained as high. The latter indicated sulfide (or sulfane) as a possible intermediate of thiocyanate oxidation. Despite the fact that cyanate was not found among the products, growth with thiocyanate induced cyanase in the cells of HRhD 2. Maximum cyanase activity $\left(200 \mathrm{nmol} \mathrm{mg}\right.$ protein ${ }^{-1} \mathrm{~min}^{-1}$ ) was found at $0.2 \mathrm{M} \mathrm{NaCl}$ and it was $75 \%$ inhibited at $2 \mathrm{M}$ $\mathrm{NaCl}$.

Mechanism of thiocyanate oxidation in strain HRhD 2

Incubation of the cells and cell-free extract under anaerobic conditions with thiocyanate resulted in thiocyanate disappearance with concomitant production of ammonium and sulfide (Table 2).

The activity was found mostly in the soluble fraction of cell-free extract. However, while the production of ammonium was in good balance with consumed thiocyanate, the sulfur balance was far from complete, indicating the formation of an intermediate. Carbonyl sulfide (COS) formation was suspected to be the case. Indeed, this gaseous compound was found to be produced as an intermediate of thiocyanate degradation in strain HRhD 2. While in growing aerobic culture its concentration was insignificant, during anaerobic incubations of washed cells, and especially in cell-free extract, COS was a major sulfur-containing product of primary thiocyanate degradation (Table 3). Further evidence favoring the "COS pathway" was obtained from the experiments on COS hydrolysis to $\mathrm{H}_{2} \mathrm{~S}$ by washed cells and cell-free extract of HRhD 2. Despite active abiotic $\mathrm{COS}$ hydrolysis at $\mathrm{pH}$ above 6 , enzymatic hydrolysis was still 1.5 times faster. The maximum
Table 2 Anaerobic primary degradation of thiocyanate by washed cells and cell free extract of strain $\mathrm{HRhD} 2$ grown with thiocyanate at $2 \mathrm{M} \mathrm{NaCl}$

\begin{tabular}{|c|c|c|c|c|}
\hline \multirow[t]{2}{*}{ Preparation } & \multirow[t]{2}{*}{ Buffer } & \multirow{2}{*}{$\begin{array}{l}\text { Rate of } \mathrm{CNS}^{-} \text {degradation } \\
\mathrm{nmol}(\mathrm{mg} \text { prot } \mathrm{h})^{-1}\end{array}$} & \multicolumn{2}{|c|}{ Product balance, $\%$} \\
\hline & & & $\mathrm{NH}_{4}^{+}$ & $\mathrm{H}_{2} \mathrm{~S} / \mathrm{HS}$ \\
\hline \multirow[t]{2}{*}{ Whole cells } & $\mathrm{pH} 7.01 \mathrm{M} \mathrm{NaCl}$ & 275 & 95 & 40 \\
\hline & $\mathrm{pH} 81 \mathrm{M} \mathrm{NaCl}$ & 240 & 92 & 64 \\
\hline Cell-free extract & $\mathrm{pH} 7.00 .2 \mathrm{M} \mathrm{NaCl}$ & 180 & 102 & 13 \\
\hline
\end{tabular}


Table 3 Carbonyl sulfide formation during thiocyanate degradation by strain HRhD 2

\begin{tabular}{lllll}
\hline Type of incubation & \multicolumn{2}{l}{ Incubation conditions } & \multicolumn{2}{l}{$\begin{array}{l}\text { COS, \% from } \\
\text { converted } \\
\text { CNS }^{-}\end{array}$} \\
\cline { 2 - 5 } & $\mathrm{NaCl}(\mathrm{M})$ & $\mathrm{pH}$ & $\mathrm{O}_{2}$ & 0.16 \\
\hline Growing culture & 1.5 & 7.5 & Aerobic & 3.0 \\
Washed cells & 1.0 & 7.0 & & 28.7 \\
Cell-free extract & 1.0 & 7.3 & Anaerobic & 23.0 \\
\hline
\end{tabular}

enzymatic rate of COS hydrolysis at $\mathrm{pH} 8$ was $2 \mathrm{nmol}$ $\mathrm{H}_{2} \mathrm{~S}$ (mg protein min) ${ }^{-1}$.

The enzyme responsible for the thiocyanate hydrolysis, with an apparent molecular weight of $140 \mathrm{kDa}$ (Fig. 3a), was partially purified in two chromatography steps from the cell-free extract of strain HRhD 2 grown with thiocyanate at $2 \mathrm{M} \mathrm{NaCl}$. It hydrolyzed thiocyanate to ammonium and sulfide with a maximum rate of $6 \mu \mathrm{mol}(\mathrm{mg} \text { prot } \mathrm{min})^{-1}$ and $\mathrm{K}_{\mathrm{s}}=6 \mathrm{mM}$. $\mathrm{NaCl}$ inhibition of the activity at concentrations near $50 \mathrm{mM}$ most likely indicate intracellular localization of the enzyme. Electrophoresis under denaturing conditions showed a presence of three major subunits with molecular weight 29,19 and $17 \mathrm{kDa}$ and one minor polypeptide of $14 \mathrm{kDa}$ (Fig. 3b). The latter turned out to be a subunit of the enzyme cyanase, which was tightly associated with the thiocyanate hydrolase. Its apparent native molecular weight was $70 \mathrm{kDa}$ (Fig. 3a). Use of a second anion-exchange column allowed separation of the cyanase from the thiocyanate hydrolase without substantial loss in the activity of the latter. Further characterization of both enzymes is currently in progress.
Identification of the isolates

Phylogenetic analysis of the halophilic thiodenitrifying coculture placed both of its members into the Gammaproteobacteria as new lineages (Fig. 4). The nitritereducing and thiocyanate-utilizing strain HRhD 2 clustered with a group of marine thiodenitrifyers (Sievert and Muyzer, unpublished), while the nitrate-reducing $\mathrm{HRhD} 3 \mathrm{sp}$ is a separate species within a new group of moderately halophilic complete thiodenitrifyers recently discovered in hypersaline habitats (Sorokin et al. 2006). Strains HRhD 2 and HRhD 3sp are deposited in DSMZ (Germany) and UNIQEM (Russia) culture collections under the numbers DSM 16326/DSM 16925 and $\mathrm{U} 231 / \mathrm{U} 247$, respectively.

\section{Discussion}

Denitrification in a binary culture

Previously we reported a case of selection of a binary thiodenitrifying culture consisting of nitrate-reducing
Fig. 3 Protein electrophoresis results showing purification of thiocyanate hydrolase and cyanase from halophilic strain HRhD 2. a $-7.5 \%$ native gel, $\mathrm{b}-12.5 \%$ SDS gel; $\mathrm{M}$ - markers, (1) active fraction after gel-filtration step; (2) and (3) - separation of thiocyanate hydrolase and cyanase by second anion chromatography step; $\mathrm{TH}-$ thiocyanate hydrolase, $\mathrm{C}$ - cyanase

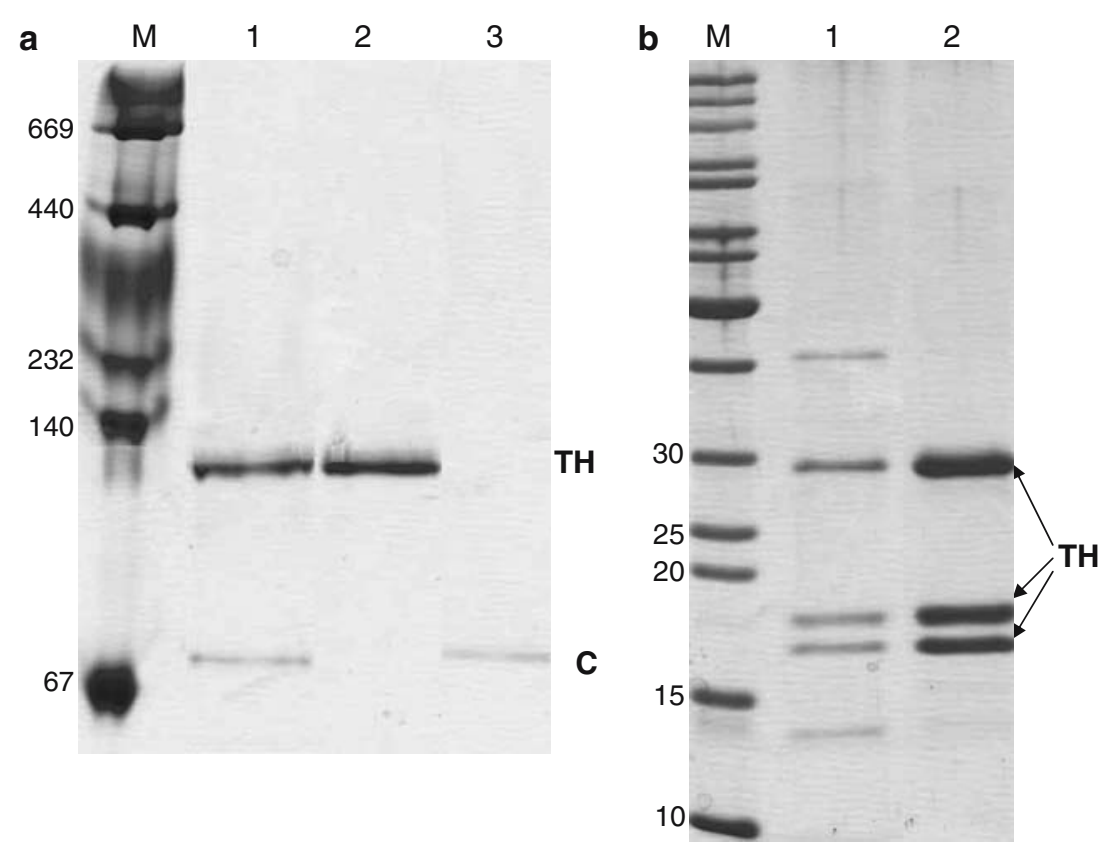


Fig. 4 Phylogenetic position of the representative strains of binary halophilic thiodenitrifying culture within the Gammaproteobacteria based on 16S rRNA gene sequence analysis. Tree topography and evolutionary distances are given by the neighbor-joining method with Jukes and Cantor distances. Numbers at the nodes indicate the percentage of bootstrap values for the clade in 1000 replications. Only values above $90 \%$ are shown

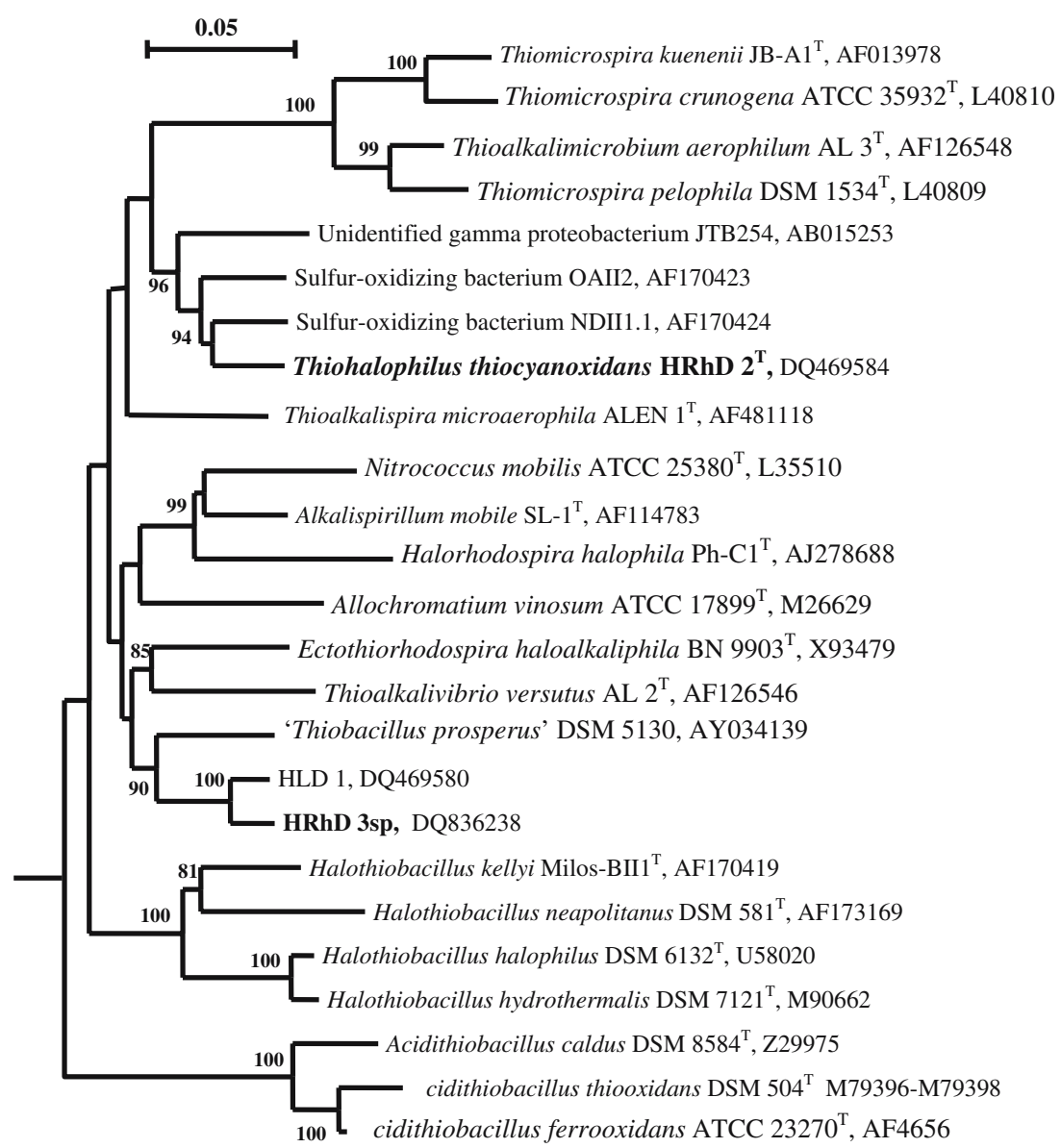

and nitrite-reducing specialized SOB under haloalkaline conditions with thiosulfate as the electron donor (Sorokin et al. 2003a). A single-organism capable of complete denitrification under alkaline conditions was found when thiocyanate was used instead of thiosulfate (Sorokin et al. 2004). In the case of halophiles, however, the situation is the opposite: with thiosulfate as the electron donor, complete thiodenitrifyers were dominated in the enrichments from hypersaline habitats (genus "Thiohalomonas", Sorokin et al. 2006), while substitution of thiosulfate by thiocyanate made development of the latter impossible and resulted in the selection of a tandem of two incomplete halophilic thiodenitrifyers. Interestingly, the nitrate-reducing member of the halophilic coculture, strain HRhD 3sp, belongs to the abovementioned group of complete halophilic thiodenitrifyers of the new genus "Thiohalomonas" as a separate species.

The question of feasibility and reasons that lay behind the phenomenon of "tandem" instead of singleorganism conversions has recently been addressed in a theoretical paper using two-stage autotrophic nitrification as a well-known example (Costa et al. 2006). The authors believe that the growth kinetics (growth rate versus growth yield) and the substrate fluxes might be an important factor. In general, high substrate fluxes favor fast growing organisms specialized on short pathways, such as incomplete nitrifiers or other incomplete oxidizers, outcompeting other organisms on the basis of fast growth. Slow growing, high yield organisms have an advantage at low substrate flow in biofilms. In the case of alkaliphilic thiodenitrification this explanation is also true, e.g. an "easy and fast" electron donor (thiosulfate) selects for incompletely denitrifying specialists, while a "difficult and slow" substrate (thiocyanate) allowed the selection of slowly growing, but complete thiodenitrifiers. In the case of halophilic thiodenitrification the opposite result can not be explained only from kinetic point of view. We suspect that in this case toxicity of the intermediate (nitrite) is more important. At high $\mathrm{pH}$ nitrite is much less toxic and, therefore, could be accumulated at much higher concentration before it starts affecting the denitrifiers. At neutral $\mathrm{pH}$ nitrite becomes toxic for the nitratereducing strain $\mathrm{HRhD} 3 \mathrm{sp}$ at $3 \mathrm{mM}$ and for the nitritereducing strain $\mathrm{HRhD} 2$ at $1 \mathrm{mM}$. Therefore, its accumulation must be kept in check, making thiocyanate a better choice for this tandem culture. On the other hand, complete halophilic denitrifyers growing fast with thiosulfate rapidly produce but also rapidly 
reduce nitrite and can tolerate up to $5 \mathrm{mM}$ (Sorokin et al. 2006). Interestingly, this difference was only important during the selection. Once isolated, the halophilic tandem grew actively with thiosulfate as the electron donor without any intermediate production of nitrite, thus being more successful than complete halophilic denitrifiers. One of the questions remaining unanswered is which organism was responsible for the thiocyanate-dependent nitrate reduction in the halophilic denitrifying enrichment? Since the final binary culture was obtained with thiosulfate and its nitratereducing member, strain $\mathrm{HRhD} 3 \mathrm{sp}$, was unable to grow with thiocyanate, it can be concluded that the bacterium performing thiocyanate-dependent nitrate reduction at halophilic conditions was lost during the switch to thiosulfate.

Thiocyanate metabolism in halophilic strain HRhD 2

Strain HRhD 2 represents a first example of a SOB able to grow with thiocyanate in $\mathrm{NaCl}$ brines, although the growth rate at salt concentrations above $2 \mathrm{M}$ was dramatically decreased. In contrast to haloalkaliphilic thiocyanate-utilizing SOB (Sorokin et al. 2001 b; 2004), the halophilic strain HRhD 2 did not produce significant amounts of cyanate during thiocyanate degradation. The same was true for the neutrophilic Thiobacillus thiocyanoxidans (now Thiobacillus thioparus) notwithstanding a "cyanate $\left(\mathrm{CNO}^{-}\right)$pathway" for primary thiocyanate degradation being implicated on the basis of high cyanase activity induced by thiocyanate (Youatt 1954). Strain HRhD 2 was also found to induce high cyanase activity during growth on thiocyanate. Nevertheless, this bacterium most probably employs the "COS pathway" of thiocyanate hydrolysis at nitrile bond (Kelly and Baker 1990):

$$
\mathrm{N}_{\overline{4}} \mathrm{C}-\mathrm{S}+\mathrm{H}_{2} \mathrm{O} \longrightarrow \mathrm{O}=\mathrm{C}=\mathrm{S}+\mathrm{H}_{2} \mathrm{O} \longrightarrow \mathrm{CO}_{2}+\mathrm{H}_{2} \mathrm{~S} \longrightarrow \mathrm{SO}_{4}^{2+}
$$

The reason(s) for the presence of cyanase is unclear, but a similar situation seemed to be observed with a methylotrophic bacterium utilizing thiocyanate as the nitrogen source (Wood et al. 1998). The "COS pathway" was described in one of the strains of Thiobacillus thioparus and the enzyme, responsible for the conversion of thiocyanate to COS and ammonium, is known as thiocyanate hydrolase (Katayama and Kuraishi 1978; Katayama et al. 1992; 1993). It contains three subunits, structurally related to the family of Co-containing nitrile-hydratases (Katayama et al. 1998; 2006). Our preliminary enzymology results indicate that the halophilic strain HRhD 2 most likely contains the same type of thiocyanate-hydrolyzing enzyme, despite its different phylogenetic position (Gammaproteobacteria instead of Betaproteobacteria). The specific enzyme (if it exists) hydrolyzing COS ("COS hydrolase") has never been studied in thiocyanate-utilizing SOB. One possibility is that cyanase might be responsible for the COS hydrolysis, which would explain its presence and tight association with the thiocyanate hydrolase in the absence of the formation of its true substrate (cyanate). Another possibility could be that thiocyanate hydrolase is nonspecifically involved in the COS hydrolysis. In any case, further enzymological work is necessary to fully understand the mechanism of thiocyanate degradation in HRhD 2.

The moderately halophilic, thiocyanate-utilizing and nitrite-reducing strain HRhD 2 represents a new lineage within the Gammaproteobacteria different from any recognized genera. It also has unique phenotypic properties. On the basis of its genetic and phenotypic properties, strain HRhD 2 is proposed to be assigned into a new genus and species Thiohalophilus thiocyanoxidans.

The nitrate-reducing strain $\mathrm{HRhD} 3 \mathrm{sp}$, together with a number of moderately halophilic complete thiodenitrifying isolates from hypersaline lakes (Sorokin et al. 2006), will be described separately elsewhere as a separate species of a new genus "Thiohalomonas".

\section{Description of Thiohalophilus gen. nov}

(thi.o.ha.lo.phi'lus. Gr.n. thios sulfur; Gr. n. hals, halos salt of the sea; Gr. adj. philos loving;

N. L. neut. n. Thiohalophilus sulfur and salt loving).

The cells are nonmotile long rods with a Gram-negative cell wall. Obligately chemolithoautotrophic and facultatively anaerobic. Utilizes reduced sulfur compounds, including thiocyanate, as the electron donor with oxygen or nitrite as the electron acceptors. Moderately halophilic. A member of the Gammaproteobacteria. Habitat - hypersaline lakes.

\section{Description of Thiohalophilus thiocyanoxidans sp. nov}

(thi.o.cyan.ox.'i.dans. Gr.n. thios sulfur; Gr.adj. cyan blue; N. L. n. thiocyanatum thiocyanate; N. L. v. oxido to oxidize; M. L. part adj. thiocyanoxidans oxidizing thiocyanate).

Cells are thin nonmotile rods of variable size (0.35-0.4 $\times 2-6 \mu \mathrm{m})$ with a Gram-negative type of cell wall. During aerobic growth a membrane-bound yellow pigment is produced. Obligately chemolithoautotrophic. Utilize sulfide, thiosulfate and thiocyanate as the electron donor 
with sulfate as the final oxidation product. Thiocyanate is degraded through the "COS pathway" with an enzyme of the thiocyanate hydrolase type. Cells grown with thiocyanate have cyanase activity. Facultatively anaerobic, utilizing nitrite as an alternative electron acceptor. Moderately halophilic with a salinity range for growth from 1.0 to $4.0 \mathrm{M} \mathrm{NaCl}$ and an optimum at $1.5 \mathrm{M}$. The $\mathrm{pH}$ range for growth is from 6.5 to 8.2 with an optimum at $\mathrm{pH}$ 7.5. The presence of high amounts of iso-heptadecenic acid (i17:1 $\omega 5$ ) is a unique signature of the species. Other dominant cellular fatty acids are 16:0 and 16:1 $\omega 7$. The $\mathrm{G}+\mathrm{C}$ content of the DNA is $58.2 \mathrm{~mol} \%\left(T_{\mathrm{m}}\right)$. Isolated from the sediments of hypersaline lakes in SW Siberia (Russia). The type strain, HRhD $2^{\mathrm{T}}$, is deposited in DSMZ and UNIQEM culture collections under the numbers DSM 16326 and U231, respectively. The GenBank 16S rDNA sequence accession number is DQ469584.

Acknowledgements This work was supported by NWO-RFBR grant (047.011.2004.010), RFBR (grant 04-04-48647), and by the Program on Molecular and Cell Biology RAS.

\section{References}

Costa E, Pérez J, Kreft J-U (2006) Why is metabolic labour divided in nitrification? Trends Microbiol 14:213-219

Davis BJ (1964) Disk electrophoresis. Method and application to human serum proteins. Ann. N.Y.Acad.Sci 121:404-407

Derikx PJL, Op Den Camp HJM, Van Der Drift C, Van Griensven LJLD, Vogels GD (1990) Odorous sulfur compounds emitted during production of compost used as a substrate in mushroom cultivation. Appl Environ Microbiol 56:176-180

Katayama Y, Hashimoto K, Nakayama H, Mino H, Nojiri M, Ono T, Nyunoyar N, Yohda M, Takio O, Odaka M (2006) Thiocyanate hydrolase is a cobalt-containing metalloenzyme with a cysteine-sulfinic acid ligand. J Amer Chem Soc. 128:728-729

Katayama Y, Kanagawa T, Kuraishi H (1993) Emission of carbonyl sulphide by Thiobacillus thioparus grown with thiocyanate in pure and mixed cultures. FEMS Microbiol Lett 114:223-228

Katayama Y, Kuraishi H (1978) Characteristics of Thiobacillus thioparus and its thiocyanate assimilation. Can J Microbiol 24:804-810

Katayama Y, Matsushita Y, Kaneko M, Kondo M, Mizuno T, Nyunoya H (1998) Cloning of genes coding for the subunits of thiocyanate hydrolase of Thiobacillus thioparus THI 115 and their evolutionary relationships to nitrile hydratase. J Bacteriol 180:2583-2589

Katayama Y, Narahara Y, Inoue Y, Amano F, Kanagawa T, Kuraishi H (1992) A thiocyanate hydrolase of Thiobacillus thioparus. A novel enzyme catalyzing the formation of carbonyl sulphide from thiocyanate. J Biol Chem 267:9170-9175

Kelly DP (1999) Thermodynamic aspects of energy conservation by chemolithotrophic sulfur bacteria in relation to the sulfur oxidation pathways. Arch Microbiol 171:219-229

Kelly DP, Baker SC (1990) The organosulfur cycle : aerobic and anaerobic processes leading to turnover of $\mathrm{C}_{1}$-sulfur compounds. FEMS Microbiol Rev 87:241-246

Kelly DP, Stackebrandt E, Burghardt J, Wood AP (1998) Confirmation that Thiobacillus halophilus and Thiobacillus hydrothermalis are distinct species within the $\gamma$-subclass of the Proteobacteria. Arch Microbiol 170:138-140

Kelly DP, Wood AP (2000) Reclassification of some species of Thiobacillus to the newly designated genera Acidithiobacillus gen. nov., Halothiobacillus gen. nov. and Thermithiobacillus gen. nov. Int J Syst Evol Microbiol 50:511-516

Laemmli UK (1970) Cleavage of structural proteins during the assembly of the head of bacteriophage T4. Nature 227:680-685

Marmur J (1961) A procedure for isolation of DNA from microorganisms. J Mol Biol 3:208-214

Murillo FM, Gugliuzzo T, Senko J, Basu P, Stolz JF (1999) A heme$C$-containing enzyme complex that exhibits nitrate and nitrite reductase activity from the dissimilatory iron-reducing bacterium Geobacter metallireducens. Arch Microbiol 172:313-320

Pfennig N, Lippert KD (1966) Über das Vitamin $B_{12}$-bedürfnis phototropher Schwefelbakterien. Arch Microbiol 55:245-256

Oren A (1999) Bioenergetic aspects of halophilism. Microbiol Mol Biol Rev 63:34-348

Schäfer H, Muyzer G (2001) Denaturing gradient gel electrophoresis in marine microbial ecology. Meth Microbiol 30:426-468

Sorokin DYu, Kuenen JG (2005 a) Haloalkaliphilic sulfur-oxidizing bacteria in soda lakes. FEMS Microbiol Rev 29:685-702

Sorokin DYu, Kuenen JG (2005 b) Alkaliphilic chemolithotrophs from sodas lakes. FEMS Microbiol Ecol 52:287-295

Sorokin DY, Kuenen JG, Jetten M (2001 a) Denitrification at extremely alkaline conditions in obligately autotrophic alkaliphilic sulfur-oxidizing bacterium Thioalkalivibrio denitrificans. Arch Microbiol 175:94-101

Sorokin DYu, Tourova TP, Lysenko AM, Kuenen JG (2001 b) Microbial thiocyanate utilization under highly alkaline conditions. Appl Environ Microbiol 67:528-538

Sorokin DYu, Tourova TP, Antipov AN, Muyzer G, Kuenen JG (2004) Anaerobic growth of the haloalkaliphilic denitrifying sulphur-oxidising bacterium Thialkalivibrio thiocyanodenitrificans sp. nov. with thiocyanate. Microbiology (UK) 150:2435-2442

Sorokin DY, Antipov AN, Kuenen JG (2003a) Complete denitrification in coculture ofobligately chemolithoautotrophic haloalkaliphilic sulphur-oxidizing bacteria from a hypersaline soda lake. Arch Microbiol 180:127-133

Sorokin DY, Tourova TP, Sjollema KA, Kuenen JG (2003b) Thioalkalivibrio nitratireducens sp. nov., a nitrate-reducing member of an autotrophic denitrifying consortium from a soda lake. Int J Syst Evol Microbiol 53:1779-1783

Sorokin DYu, Tourova TP, Lysenko AM, Muyzer G (2006) Culturable diversity of halophilic sulfur-oxidizing bacteria in hypersaline habitats. Microbiology (UK) 152:3013-3023

Van de Peer Y, De Wachter R (1994) TREECON for Windows: a software package for the construction and drawing of evolutionary trees for the Microsoft Windows environment. Comput Applic Biosci 10:569-570

Wood AP, Kelly DP (1991) Isolation and characterisation of Thiobacillus halophilus sp. nov., a sulphur-oxidizing autotrophic eubacterium from a Western Australian hypersaline lake. Arch Microbiol 156:277-280

Wood AP, Kelly DP, McDonald IR, Jordan SL, Morgan TD, Khan S, Murrell JC, Borodina E (1998) A novel pink-pigmented facultative methylotroph, Methylobacterium thiocyanatum sp. nov., capable of growth on thiocyanate or cyanate as sole nitrogen sources. Arch Microbiol 169:148158

Youatt J B (1954) Studies on the metabolism of Thiobacillus thiocyanooxidans. J Gen Microbiol 11:139-149

Zhilina TN, Zavarzin GA, Rainey FA, Pikuta EN, Osipov GA., Kostrikina NA (1997) Desulfonatronovibrio hydrogenovorans gen. nov., sp. nov., an alkaliphilic, sulfate-reducing bacterium. Int J Syst Bacteriol 47:144-149 